\title{
Characteristics of antimicrobial activity of Streptococcus salivarius K12 by culture condition
}

\author{
Young-Gyun Song ${ }^{1}$, Sung-Hoon Lee ${ }^{2} *$ \\ 'Department of Prosthodontics, College of Dentistry, Dankook University, Cheonan, Republic of Korea \\ ${ }^{2}$ Department of Oral Microbiology and Immunology, College of Dentistry, Dankook University, Cheonan, Republic of Korea
}

Purpose: The purpose of this study was to examine effects of culture conditions on the growth and antibacterial activity of Streptococcus salivarius K12. Materials and Methods: S. salivarius K12 was cultivated in medium containing animal and plant protein or in medium of neutral and acidic conditions. The growth of $S$. salivarius K12 was measured every 2 hours by a spectrophotometer. The antimicrobial activity of $S$. salivarius $\mathrm{K} 12$ against Streptococcus mutans and Porphyromonas gingivalis was investigated by the susceptibility assay using the spent culture medium. Results: the growth of $S$. salivarius K12 showed faster in medium containing plant protein and neutral pH condition. The antimicrobial and antifungal activity of $S$. salivarius K12 appeared stronger in medium containing plant protein than animal proteins. Conclusion: For application of S. salivarius K12 to bacterial oral disease, co-substances may be needed for S. salivarius K12 to colonize in the oral cavity and enhance the antimicrobial activity. (J Dent Rehabil Appl Sci 2021;37(4):244-50)

Key words: S. salivarius K12; probiotics; prebiotics; antimicrobial activity

\section{Introduction}

Major diseases induced by pathogenic bacteria are dental caries and periodontitis, and the most common fungal disease in oral cavity is candidiasis. ${ }^{1,2}$ According to epidemiological studies, dental caries is related with Streptococcus mutans and S. sobrinus, and periodontitis is caused by obligated anaerobic Gramnegative bacteria such as Porphyromonas gingivalis, Tannerella forsythia, and Treponema denticola, ${ }^{3}$ and oral candidiasis is related with Candida albicans. ${ }^{2}$ Although various research have been studied on the characteristics of these pathogens and antibiotics and physical therapy to treat oral diseases, the studies on

\footnotetext{
*Correspondence to: Sung-Hoon Lee

Assistant Professor, Department of Oral Microbiology and Immunology, College of Dentistry, Dankook University, 119 Dandae-ro, Dongnam-gu, Cheonan 31116 Republic of Korea

Tel: +82-41-550-1867, Fax: +82-41-550-1859, E-mail: dennisyi@dankook.ac.kr Received: December 9, 2021/Last Revision: December 10, 2021/Accepted:

December 10, 2021
}

prevention of oral disease are still lacking. Recently, Oral biofilms are considered to be more important than individual characteristics of these bacteria in oral diseases, and comparative studies on characteristics between healthy biofilm and pathogenic biofilm is in progress. ${ }^{4-6}$ Oral biofilms are classified according to the distribution of bacteria in the biofilm, and when the distribution of pathogenic bacteria is high levels, it is recognized as a disease-related biofilm, and when the distribution of normal flora is high levels, it is considered as a healthy biofilm. ${ }^{1}$ Therefore, the ideal prevention of oral disease is to maintain a high distribution of commensal bacteria such as viridans streptococci except mutans streptococci within the biofilm.

Copyright@ 2021 The Korean Academy of Stomatognathic Function and Occlusion. (c) It is identical to Creative Commons Non-Commercial License. 
Probiotics are live microorganisms and provide a health benefit to the host. ${ }^{7}$ Due to concerns about the emergence of antibiotics-resistant bacteria, many studies have been conducted on treatment and prevention of infectious disease using probiotics. ${ }^{8}$ Latobacilli plays an important role to maintain human healthy by stimulating native immune system and protection against infection of pathogenic bacteria. ${ }^{9}$ However, Since Lactobacillus species have characteristics of abundant production of lactic acid and aciduricity, it is careful when applying it to oral disease. Among probiotics, Streptococcus salivarius K12 is Gram-positive and facultative anaerobic bacteria. This bacterium, which is isolated from healthy person, is a pioneer colonizer of oral cavity. ${ }^{10} S$. salivarius K12 is also known to be a probiotic bacterium and produces bacteriocin of two class such as salivaricin A2 and salivaricin B. ${ }^{11}$ Above all, S. salivarius K12 don't have aciduricity like Lactobacillus species. The selection of prebiotics as well as probiotics is important for treatment and prevention of disease. Prebiotics are defined "dietary prebiotics" as "a selectively fermented ingredient that results in specific changes in the composition and/or activity of the gastrointestinal microbiota, thus conferring benefit(s) upon host health". ${ }^{12}$ Eventually, prebiotics for oral cavity can selectively influence oral microbiota, and it is necessary to find suitable prebiotics to enhance the growth and antimicrobial activity of S. salivarius K12

Although, S. salivarius K12 showed antimicrobial activity against oral bacteria, ${ }^{13}$ There are insufficient information on the culture conditions optimized to apply S. salivarius K12 to the oral cavity. The purpose of this study was to investigate effects of culture conditions on the growth and antibacterial activity of S. salivarius $\mathrm{K} 12$

\section{Materials and Methods}

S. salivarius K12 was donated from Green store Inc. (Seongnam, Korea) and used in this study after isolating from Bactoblis ${ }^{\circledR}$ tablet. S. salivarius $\mathrm{K} 12$ was cultivated with M17 broth (BD bioscience, Sparks, USA). For susceptibility assay, a species of Grampositive and Gram-negative bacteria were selected, respectively, and Streptococcus mutans ATCC 25175, Porphyromonas gingivalis ATCC 33277, and Candida albicans ATCC 10231 was selected for dental caries, periodontitis, and candidiasis, respectively. S. mutans was cultivated with Tryptic soy broth (BD bioscience, Spark, USA), and P. gingivalis was cultured with brain heart infusion (BHI; BD bioscience) supplemented with hemin $(0.5 \mu \mathrm{g} / \mathrm{ml}$; Sigmaaldrich Co., San Jose, USA) and vitamin K (0.2 $\mu \mathrm{g} / \mathrm{ml}$; Sigmaaldrich Co.). C. albicans was cultivated in tryptic soy broth (TSB; BD bioscience), The bacteria and fungus were maintained at $37^{\circ} \mathrm{C}$ in an aerobic condition $\left(\mathrm{H}_{2} 5 \%, \mathrm{CO}_{2} 10 \%\right.$, and $\mathrm{N}_{2} 85 \%$ ) and an aerobic condition, respectively. In investigate characteristics of $S$. salivarius $\mathrm{K} 12$ by culture conditions, $S$. salivarius $\mathrm{K} 12$ was cultured with media of two types (medium containing animal or plant protein), and the components of two media is shown in Table 1 . In another experiment, the medium containing plant protein was added with 10 $\mathrm{mM}$ sodium phosphate dibasic and $2 \mathrm{mM}$ potassium phosphate, monobasic and then adjusted the level of $\mathrm{pH} 7.0$ and $\mathrm{pH} 5.5$ with lactic acid. S. salivarius K12 was cultured in the two conditions. The growth of $S$. salivarius $\mathrm{K} 12$ cultured in various conditions was measured optical density at $660 \mathrm{~nm}$ of wavelength every 2 hours. After collecting spent culture medium (SCM) of S. salivarius K12 cultured in various conditions, the SCM from various condition was investigated

Table 1. The component of media containing animal and plant protein

\begin{tabular}{lll}
\hline & Medium containing animal protein & Medium containing plant protein \\
\hline \multirow{3}{*}{ Formula } & Peptic digest of animal tissue & Peptic digest of soybean meal \\
& Pancreatic digest of casein & Pancreatic digest of casein \\
& Yeast extract & Yeast extract \\
& Sodium chloride & Sodium chloride \\
& Glucose & Glucose \\
& Sodium phosphate dibasic & Sodium phosphate dibasic \\
\hline
\end{tabular}


antimicrobial activity against oral bacteria according to Clinical and Laboratory Standard Institute (CLSI) guidelines. Briefly, $180 \mu \mathrm{l}$ of the specific medium for each oral microbe was dispensed into 96-well plate (SPL Lifescience, Pocheon, Korea), and the SCM was added into the first row. The SCM was performed 2 -fold serial dilution with micropipette. The bacterial suspensions were adjusted $2 \times 10^{6}$ cells $/ \mathrm{ml}$ for $S$. mutans, $3 \times 10^{6}$ cells $/ \mathrm{ml}$ for $P$. gingivalis, and 1 $\times 10^{6}$ cells $/ \mathrm{ml}$ of Candida albicans after counting the bacteria using a bacterial counting chamber (Hausser Scientific, Horsham, USA). $20 \mu$ l of the bacterial suspension was inoculated into the prepared well with diluted SCM, and the plate was incubated at $37^{\circ}$ $\mathrm{C}$ in an aerobic condition $\mathrm{H}_{2} 5 \%, \mathrm{CO}_{2} 10 \%$, and $\mathrm{N}_{2}$ $85 \%$ ). The growth of bacteria was measured optical density at $660 \mathrm{~nm}$ of wavelength by a spectrophotometer (BioTek, Winooski, USA). The significant difference among each group was analyzed by nonparametrical analysis such as Kruskal Wallis test and Mann-Whitney U test using IBM SPSS statistics Ver. 23 (IBM, Armonk, USA). P-values less than 0.05

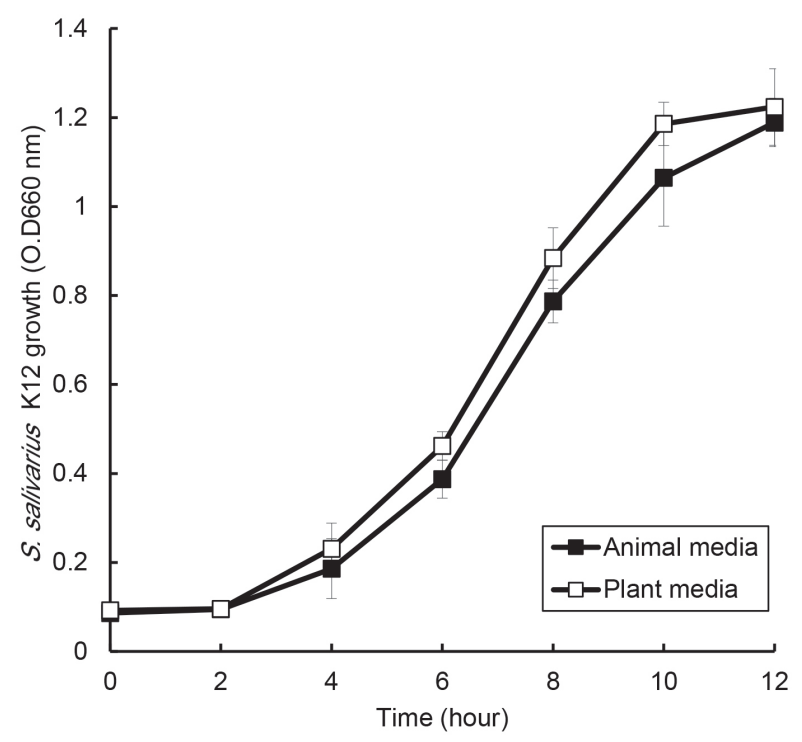

Fig. 1. Comparison of effects of animal and plant protein on the growth of S. salivarius K12. S. salivarius K12 was cultured with medium containing animal and plant protein, and the growth of this bacterium was measured every 2 hours by optical density using a spectrophotometer. The experiments were carried out three times in triplicate, and data are expressed as mean \pm standard deviation. were considered statistically significant.

\section{Results}

When the growth of S. salivarius K12 using medium of animal protein and plant protein was investigated, although the growth of $S$. salivarius did not show significant difference between medium containing animal and plant protein, the its growth was slightly faster in presence of plant protein than animal protein (Fig. 1). The growth of $S$. salivarius $\mathrm{K} 12$ in Also, when the effects of $\mathrm{pH}$ level on the growth of S. salivarius K12 were examined, S. salivarius $\mathrm{K} 12$ was cultured very slow and did not reach stationary phase in the medium of pH 5.5 (Fig. 2). On other hand, the growth of S. salivarius K12 in $\mathrm{pH}$ 7.0 condition showed S shaped growth curve (Fig. 2). In case of $S$. salivarius K12 growth in two $\mathrm{pH}$ levels, there were a lot of growth differences to compare the antimicrobial activity of $S$. salivarius K12. Therefore, the antimicrobial activity of $S$. salivarius K12 cultured in medium containing animal or plant pro-

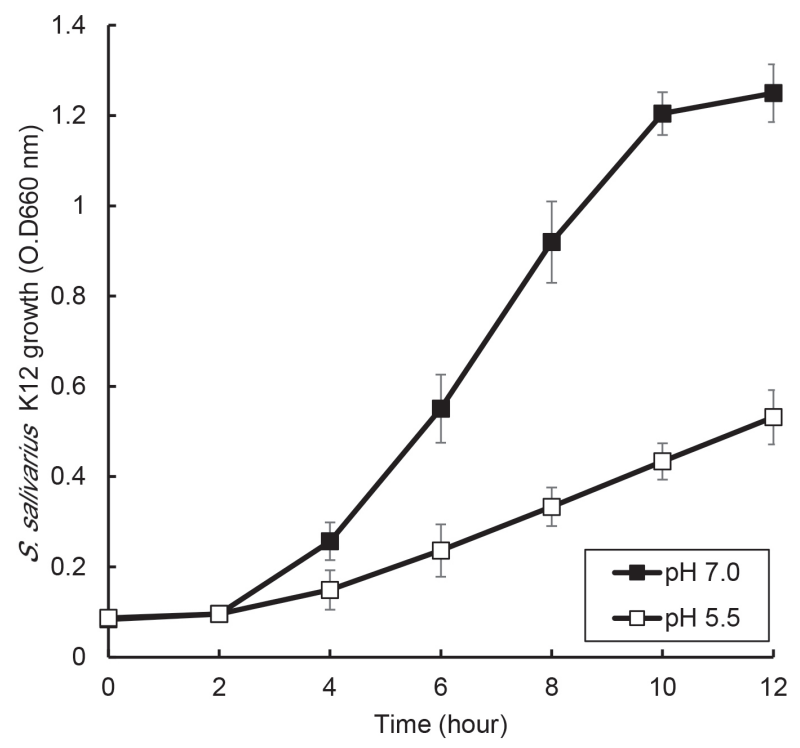

Fig. 2. Comparison of effects of $\mathrm{pH}$ condition on the growth of S. salivarius K12. S. salivarius K12 was cultured in medium with $\mathrm{pH} 7.0$ and $\mathrm{pH} 5.5$, and the growth of this bacterium was measured every 2 hours by optical density using a spectrophotometer. The experiments were carried out three times in triplicate, and data are expressed as mean \pm standard deviation. ${ }^{*}$ indicates statistically significant differences between the two conditions. 
A

S. mutans

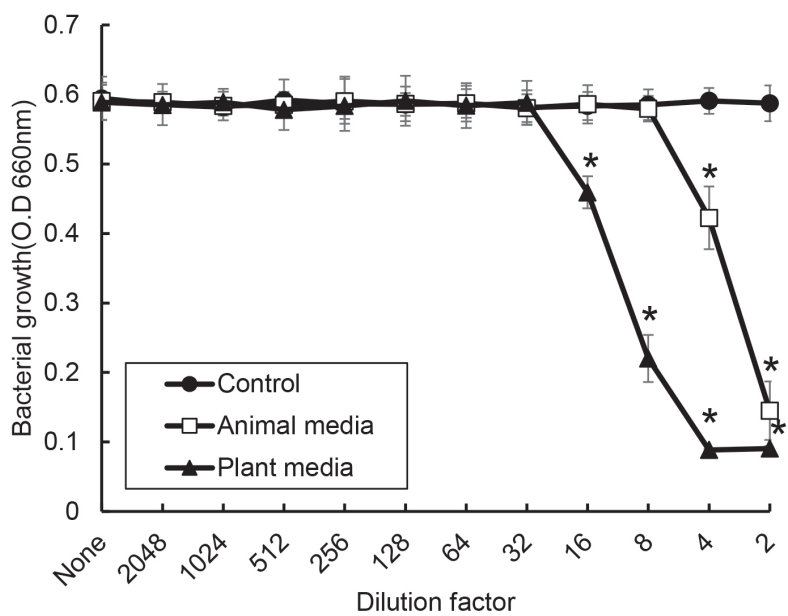

B P. gingivalis

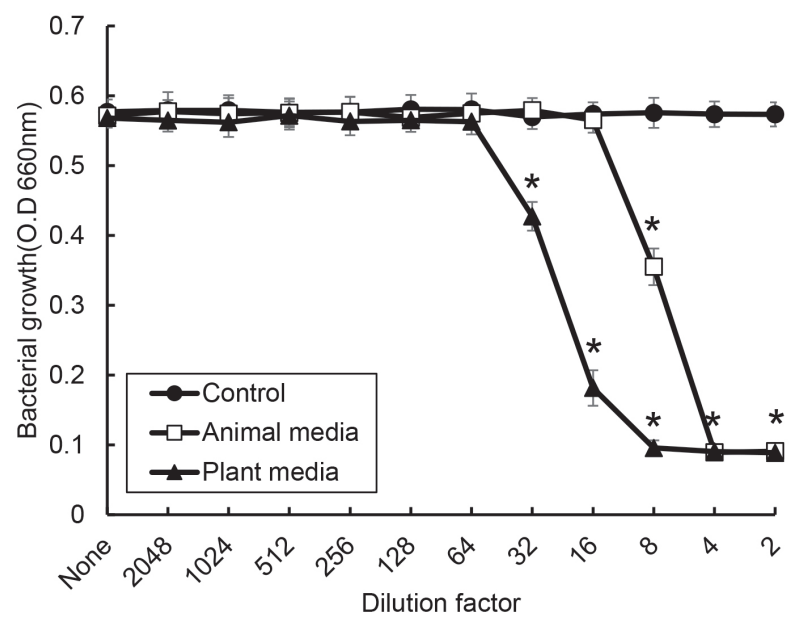

Fig. 3. Antimicrobial activity of $S$. salivarius $K 12$ against oral bacteria. The spent culture medium was collected from S. salivarius K12 cultured with medium containing animal and plant protein. S. mutans (A) and P. gingivalis (B) was incubated in the presence or absence of the SCM of S. salivarius K12. Bacterial growth was measured by a spectrophotometer. The experiments were carried out 4 times in duplicate, and data are expressed as mean \pm standard deviation. ${ }^{*}$ indicates statistically significant differences compared control group.

teins was compared using SCM. The SCM of $S$. salivarius $\mathrm{K} 12$ cultured in medium containing animal and plant proteins significantly inhibited the growth of $S$. mutans at or above 4-fold diluted and 16-fold diluted concentration, respectively $(P<0.05)$ (Fig. 3A). The difference in antimicrobial activity of $S$. salivarius K12 cultured in the two media was approximately 4 times. Also, in case of examination of P. gingivalis, the SCM of the probiotics cultured in medium containing animal and plant protein significantly reduced the growth of $P$. gingivalis at or above 8-fold and 32-fold diluted concentration, respectively $(P<0.05)$ (Fig. 3B). Similar to the case of $S$. mutans, the two SCM of $S$. salivarius K12 showed 4 times difference in the antimicrobial activity against $P$. gingivalis. The SCM of S. salivarius $\mathrm{K} 12$ cultured in medium containing plant proteins significantly inhibited the growth of C. albicans at or above 4-fold diluted concentration ( $P$ $<0.05$ ) (Fig. 4). The SCM from medium containing animal protein slightly inhibited the growth of C. albicans.

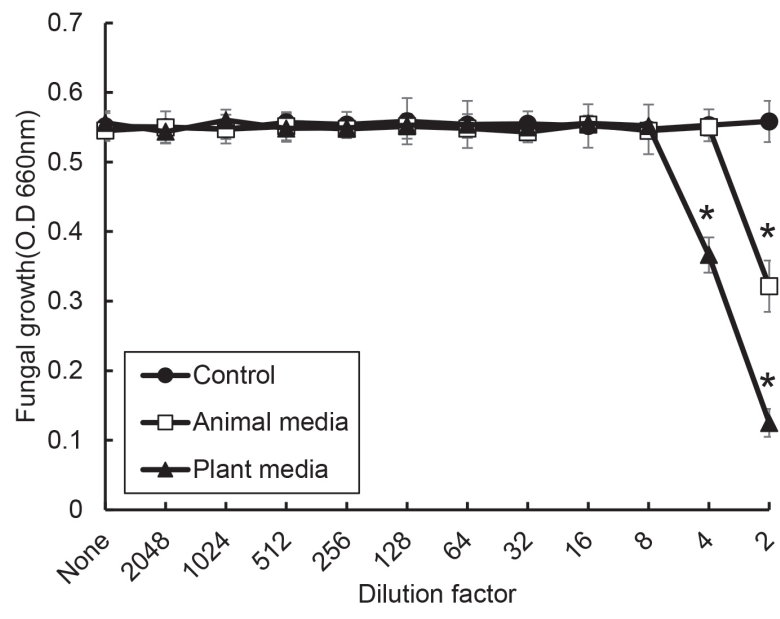

Fig. 4. Antifungal activity of S. salivarius K12 against C. albicans. The spent culture medium was collected from S. salivarius K12 cultured with medium containing animal and plant protein. C. albicans was incubated in the presence or absence of the SCM of S. salivarius K12. Fungal growth was measured by a spectrophotometer. The experiments were carried out 3 times in duplicate, and data are expressed as mean \pm standard deviation. * indicates statistically significant differences compared control group. 


\section{Discussion}

S. salivarius $\mathrm{K} 12$ is a probiotic bacterium and isolated from the saliva of healthy child. ${ }^{14}$ This probiotic produces salivaricin A2 and salivaricin B that effectively inhibits the growth of S. pyogenes as a pharyngitis related bacterium. ${ }^{15,16}$ Furthermore, S. salivarius K12 has the antimicrobial activity against oral bacteria and fungus and can colonize in oral cavity. ${ }^{13,17}$ Due to these characteristics, $S$. salivarius K12 is considered to be more suitable for prevention and treatment of bacteria-related oral disease than other probiotics. However, there is still not enough information about the habit of $S$. salivarius K12. Therefore, in this study, the growth and antimicrobial activity of $S$. salivarius K12 according to the culture condition were investigated.

S. salivarius K12 showed faster growth in medium containing plant protein than animal proteins. Probiotics require nutrients and environments for colonization and growth like pathogenic bacteria because of protozoa. So, substances that help the function and growth of probiotics are called prebiotics, and oligosaccharide is representative. In this study, although it has not been examined exactly what component, it was observed that a protein derived from soybean, a representative plant protein, helps the growth of S. salivarius K12. This indicates that soy protein may be a prebiotic for S. salivarius K12. In experiment of $\mathrm{pH}$ levels, S. salivarius K12 was observed to grow very slowly in $\mathrm{pH} 5.5$ as an acidic condition. Most bacteria produce lactic acid through carbohydrate metabolism and create the acidic environment. Even in a $\mathrm{pH} 5.5$ environment, if $S$. salivarius $\mathrm{K} 12$ is active in carbohydrate metabolism, it can induce dental caries, but it is considered that $S$. salivarius $\mathrm{K} 12$ may slowly metabolize because the growth is slow in this environment. Therefore, this information supports that $S$. salivarius $\mathrm{K} 12$ is safe to apply for the prevention of oral diseases, and that substances with a $\mathrm{pH}$ buffer function may be included to increase the preventive effect of $S$. salivarius K12.

In order to investigate whether the two media affects only the growth of $S$. salivarius K12 or affects the antimicrobial and the antifungal activity of $S$. salivarius $\mathrm{k} 12$, the susceptibility of $S$. mutans and $P$. gingivalis was evaluated using the SCM of $S$. salivarius K12 cultured in medium containing animal or plant protein. S. mutans is a Gram-positive microbe and closely related with dental caries, ${ }^{7}$ and $P$. gingivalis is a Gram-negative anaerobe and a periodontopathogen. ${ }^{3}$ Both bacteria showed more susceptibility for the SCM from medium containing plant protein than animal protein. Furthermore, C. albicans appeared more susceptibility for the SCM from medium containing plant protein compared to animal protein

\section{Conclusion}

The present study shown that the necessity of the condition to maximize the function of $S$. salivarius K12 as a probiotic. Eventually, in order to apply $S$. salivarius K12 to bacterial oral disease, co-substances may be needed for $S$. salivarius $\mathrm{K} 12$ to colonize in the oral cavity and exhibit stronger the antimicrobial activity.

\section{ORCID}

Young-Gyun Song https://orcid.org/0000-0003-3789-9585

Sung-Hoon Lee https://orcid.org/0000-0002-8852-0419

\section{References}

1. Marsh PD. Microbial ecology of dental plaque and its significance in health and disease. Adv Dent Res 1994;8:263-71.

2. Song YG, Lee SH. Inhibitory effects of Lactobacillus rhamnosus and Lactobacillus casei on Candida biofilm of denture surface. Arch Oral Biol 2017;76: 1-6.

3. Holt SC, Ebersole JL. Porphyromonas gingivalis, Treponema denticola, and Tannerella forsythia: the "red complex", a prototype polybacterial pathogenic consortium in periodontitis. Periodontol 2000 2005;38:72-122.

4. Schoilew K, Ueffing H, Dalpke A, Wolff B, Frese C, Wolff $\mathrm{D}$, Boutin S. Bacterial biofilm composition in healthy subjects with and without caries experience. J Oral Microbiol 2019;11:1633194. 
5. Velsko IM, Shaddox LM. Consistent and reproducible long-term in vitro growth of health and disease-associated oral subgingival biofilms. BMC Microbiol 2018;18:70.

6. Shaddox LM, Spencer WP, Velsko IM, Al-Kassab H, Huang H, Calderon N, Aukhil I, Wallet SM. Localized aggressive periodontitis immune response to healthy and diseased subgingival plaque. J Clin Periodontol 2016;43:746-53.

7. Lee SH, Kim YJ. A comparative study of the effect of probiotics on cariogenic biofilm model for preventing dental caries. Arch Microbiol 2014;196:6019.

8. Mah TF, O'oole GA. Mechanisms of biofilm resistance to antimicrobial agents. Trends Microbiol 2001;9:34-9.

9. Gill H, Prasad J. Probiotics, immunomodulation, and health benefits. Adv Exp Med Biol 2008;606: 423-54.

10. Rath H, Feng D, Neuweiler I, Stumpp NS, Nackenhorst U, Stiesch M. Biofilm formation by the oral pioneer colonizer Streptococcus gordonii: an experimental and numerical study. FEMS Microbiol Ecol 2017;93. doi: 10.1093/femsec/fix010.

11. Hyink O, Wescombe PA, Upton M, Ragland N, Burton JP, Tagg JR. Salivaricin A2 and the novel lantibiotic salivaricin $\mathrm{B}$ are encoded at adjacent loci on a 190-kilobase transmissible megaplasmid in the oral probiotic strain Streptococcus salivarius K12. Appl Environ Microbiol 2007;73:1107-13.

12. Davani-Davari D, Negahdaripour M, Karimzadeh I, Seifan M, Mohkam M, Masoumi SJ, Berenjian A, Ghasemi Y. Prebiotics: Definition, Types, Sources, Mechanisms, and Clinical Applications. Foods 2019;8:92

13. Moon YM, Moon JE, Lee MR, Cho JW. Antibacterial Effects of Streptococcus Salivarius K12 on Oral Bacteria. Int J Clin Prev Dent 2016;12:209-20.

14. Tagg JR. Prevention of streptococcal pharyngitis by anti-Streptococcus pyogenes bacteriocin-like inhibitory substances (BLIS) produced by Streptococcus salivarius. Indian J Med Res 2004;119:13-6.

15. Burton JP, Chilcott CN, Wescombe PA, Tagg JR. Extended Safety Data for the Oral Cavity Probiotic Streptococcus salivarius K12. Probiotics Antimi- crob Proteins 2010;2:135-44.

16. Di Pierro F, Adami T, Rapacioli G, Giardini N, Streitberger C. Clinical evaluation of the oral probiotic Streptococcus salivarius K12 in the prevention of recurrent pharyngitis and/or tonsillitis caused by Streptococcus pyogenes in adults. Expert Opin Biol Ther 2013;13:339-43.

17. Mokhtar M, Rismayuddin NAR, Yassim ASM, Ahmad H, Wahab RA, Dashper S, Arzmi MH. Streptococcus salivarius K12 inhibits Candida albicans aggregation, biofilm formation and dimorphism. Biofouling 2021;37:767-76. 


\section{Streptococcus salivarius $\mathrm{K} 12$ 의 배양조건에 따른 항균활성의 특징}

송영균 ${ }^{1}$ 부교수, 이성훈 ${ }^{2 *}$ 조교수

${ }^{1}$ 단국대학교 치과대학 보철학교실

${ }^{2}$ 단국대학교 치과대학 구강미생물학교실

목적: 본 연구의 목적은 Streptococcus salivarius K12의 성장과 항균활성에 대한 배양조건의 영향을 알아보는 것이다.

연구 재료 및 방법: S. salivarius K12는 동물 또는 식물 단백질을 함유한 배지 또는 중성 및 산성 조건의 배지에서 배양되 었다. S. salivarius K12의 성장은 2시간마다 분광광도계로 측정하였다. S. salivarius K12의 Streptococcus mutans, Porphyromonas gingivalis 및 Candida albicans에 대한 항균 또는 항진균 활성을 배양액을 이용한 감수성 분석으로 조사하였다.

결과: S. salivarius $\mathrm{K} 12$ 의 성장은 식물 단백질과 중성 $\mathrm{pH}$ 조건에서 더 빠른 성장을 보였다. S. salivarius $\mathrm{K} 12$ 의 항균 및 항 진균 활성은 동물성 단백질보다 식물성 단백질을 함유한 배지에서 더 강하게 나타났다.

결론: S. salivarius K12를 세균성 구강질환에 적용하기 위해서는 S. salivarius K12가 구강 내에서 군집화하여 항균 활성을 향상시키기 위한 보조물질이 필요할 수 있다.

(구강회복응용과학지 2021;37(4):244-50)

주요어: S. salivarius K12; 프로바이오틱스; 프리바이오틱스; 항균 활성 